\title{
Endogenous Structure of the Division of Labor, Endogenous Trade Policy Regime, and a Dual Structure in Economic Development
}

\author{
Xiaokai Yang \\ Department of Economics, Monash University \\ Clayton, Victoria, 3800, Australia \\ and \\ Dingsheng Zhang \\ Institute for Advanced Study, Wuhan University \\ Wuhan, 430072, China
}

\begin{abstract}
This paper develops a general equilibrium model with transaction costs and endogenous and exogenous comparative advantages. The governments are allowed to choose between tariff war, tariff negotiation, and a laissez faire regime. It shows that the level of the division of labor and trade increases as transaction conditions improve. When a high level of the division of labor occurs in general equilibrium, all countries prefer Nash tariff bargaining game that would result in multilateral free trade. If a medium level of the division of labor occurs in general equilibrium, then unilateral protection tariff in a less developed country and unilateral laissez faire policies in a developed country would coexist. The results show that tariff negotiations are essential for achieving multilateral free trade. In addition, the model may explain the policy transition of some European governments from mercantilism to free-trade regime in the 18th and 19th century and policy changes in developing countries from protection tariff to tariff negotiation and trade liberalization. Journal of Economic Literature Classification Numbers: D30, F10, O10. (c) 2000 Peking
\end{abstract} University Press

Key Words: Endogenous structure of the division of labor; Dual economy; Endogenous trade policy regime. 


\section{INTRODUCTION}

It is a well-accepted idea that free international trade benefits all countries involved; it is also a well-known fact that hardly any country has always been practicing free-trade policies. Why do countries deviate from the free-trade regime? Traditional trade theory contends that governments set up trade barriers because of political pressure from interest groups. Since imports competition poses a threat to some domestic industries, these industries lobby intensely for trade protection (Krueger, 1974, Pincus, 1975, Mayer, 1984). Other studies suggest that governments are tempted to use trade bargaining to get a larger share of the gains from trade (see, for instance, Morishima, 1989). We can identify three lines of research in trade bargaining. The first line builds on the theory of optimum tariff (Johnson, 1954), and uses bargaining games to model trade negotiations between governments (Mayer, 1981, Riezman, 1982). The second line of research is associated with the literature of the "new trade theory". It assumes an oligopolistic market structure in international trade, where governments adopt strategic trade policies to gain the economic rent generated by market power (Dixit and Kyle, 1985, Krugman, 1986). The third line of research views international negotiations as a two-level game: at the first level, interest groups lobby for trade policies in their favor, which determines governments' policy preference; at the second level, the negotiation between governments determines the international equilibrium (Grossman and Helpman, 1994, 1995a, 1995b).

While the existing literature provides insights as to why a particular trade regime may exist, it is silent about how it might evolve and how the equilibrium trade regime might relate to the equilibrium level of the division of labor between trading countries which is affected by transaction conditions. The purpose of this paper is to study the equilibrium level of the division of labor based on individuals' production and trade decisions, and to examine the general equilibrium implication of the inter-dependence between the level of the division of labor and the degree of trade liberation.

In this paper, we develop a Ricardian model with transaction costs and endogenous comparative advantage. In our model, individuals are consumer-producers, they choose first between self-sufficiency and trade, and then what and how much to produce and trade. The governments make decisions on trade policies: they can choose to play a Nash tariff game, to have Nash tariff negotiations, or to have laissez faire policies. We shall show that as transaction conditions improve, the equilibrium level of the division of labor increases. If a high level of the division of labor occurs in general equilibrium, each country has some power to affect the terms of trade and has an incentive to impose a tariff. If both countries play a Nash tariff game (i.e., to choose a tariff rate taking another country's tariff as 
given), there is a risk of a tariff war that can dissipate all the gains from trade. Facing this risk, all governments would prefer trade negotiations to a tariff war. A Nash tariff negotiation would result in zero tariff rates. If a medium level of the division of labor occurs in general equilibrium, i.e., one country is completely specialized in producing one good while the other produces two goods, then unilateral tariff protection and unilateral laissez faire policies would coexist.

The results of the model suggest that the development in the level and pattern of international division of labor may be a driving force behind the evolution of the international trade regime. This may explain the policy transition in some European governments from mercantilism to laissez faire in the 18th and 19th century and policy changes in developing countries from protection tariff to trade liberalization and tariff negotiation. The results also provide an economic rationale for trade negotiations and highlight the importance of trade negotiations in achieving stable trade liberalization.

Our paper is distinguished from Cheng, Sachs, and Yang (2000), in which technology displays constant returns to scale, and from Cheng, Liu, and Yang (2000), which cannot predict a dual structure with ex ante identical individuals choosing different levels of specialization (or different degrees of commercialization) and different levels of productivity.

The rest of this paper is organized as follows. Section 2 presents a simple Ricardian model with transaction costs and endogenous comparative advantage, and discusses the relationship between the transaction cost and the equilibrium level of the division of labor. Section 3 introduces government policy choices into the model and investigates the endogeneity of trade policy regimes.

\section{A GENERAL EQUILIBRIUM RICARDIAN MODEL}

\subsection{The $2 \times 2$ model}

Consider a world consisting of two countries, country 1 and country 2 , each with a continuum set of individual consumer-producers of mass $M_{i} \quad(i=1,2)$. Assume that the individuals are ex ante identical within each country and have the following utility function:

$$
U_{i}=\left(x_{i}+k_{i} x_{i}^{d}\right)^{\beta}\left(y_{i}+k_{i} y_{i}^{d}\right)^{1-\beta}
$$

where $x_{i}, y_{i}$ are quantities of goods $x$ and $y$ self-provided, and $x_{i}^{d}, y_{i}^{d}$ are quantities of the goods $x$ and $y$ bought from the market. $k_{i}\left(k_{i} \in[0,1]\right)$ is the transaction condition coefficient, which relates to an iceberg type transaction costs, for each unit of good bought, only the fraction $k_{i}$ is received by the buyer, $1-k_{i}$ is lost in transit. 
The production functions for an individual in country 1 and country 2 are:

$$
\begin{aligned}
& x_{1}+x_{1}^{s}=\max \left\{0, c\left(L_{1 x}-b\right)\right\}, y_{1}+y_{1}^{s}=L_{1 y}, \\
& x_{2}+x_{2}^{s}=\max \left\{0, c\left(L_{2 x}-b\right)\right\}, y_{2}+y_{2}^{s}=a L_{2 y},
\end{aligned}
$$

where $L_{i x}$ and $L_{i y}$ are respectively amounts of labor devoted to producing good $x$ and good $y$, and $L_{i x}+L_{i y}=2$. $x_{i}^{s}$ and $y_{i}^{s}$ are respectively amounts of good $x$ and good $y$ sold in the market. We follow Charles Babbage (1832) and Houthakker (1956) to specify an individual specific fixed learning cost in producing good $x, b$, which is caused by a trial-error learning process in production or in a training process. The production technology of good $y$ exhibits constant returns to scale. Country 2 is assumed to have exogenous comparative advantage in producing good $y$, or $a>1$.

The existence of a fixed learning cost implies that specializing in a single good would increase utilization rate of the fixed training cost and improve labor productivity (Becker, 1981, and Rosen, 1983). The relative productivity advantage obtained through decisions regarding specification is referred to as endogenous comparative advantage (Yang, 1994). Endogenous comparative advantage can be the source of the gains from trade when exogenous comparative advantage is absent. When both exogenous and endogenous comparative advantage are present, they interact with each other to determine the pattern of trade.

The decision problem for an individual in country $i$ involves deciding on what and how much to produce for self-consumption, to sell and to buy from the market. In other words, the individual chooses six variables $x_{i}, x_{i}^{s}, x_{i}^{d}, y_{i}, y_{i}^{s}, y_{i}^{d} \geq 0$. Hence, there are $2^{6}=64$ possible corner and interior solutions. As shown by Wen (1998), for such a model, an individual never simultaneously sells and buys the same good, never simultaneously produces and buys the same good, and never sells more than one good. We refer to each individual's choice of what to produce, buy and sell that is consistent with the Wen theorem as a configuration.

There are three configurations from which the individuals can choose:

(1) self-sufficiency. Configuration A, where an individual produces both goods for self-consumption. This configuration is defined by

$$
x_{i}, y_{i}>0, x_{i}^{s}=x_{i}^{d}=y_{i}^{s}=y_{i}^{d}=0, i=1,2 \text {. }
$$

(2) specialization in producing good $x$. Configuration $(x / y)$, where an individual produces only $x$, sells $x$ in exchange for $y$, is defined by

$$
x_{i}, x_{i}^{s}, y_{i}^{d}>0, x_{i}^{d}=y_{i}=y_{i}^{s}=0
$$


(3) specialization in producing good $y$. Configuration $(y / x)$, where an individual produces only $y$, sells $y$ in exchange for $x$, is defined by

$$
y_{i}, y_{i}^{s}, x_{i}^{d}>0, y_{i}^{d}=x_{i}=x_{i}^{s}=0
$$

The combination of all individual's configurations constitutes a market structure, or structure for short. Given the configurations listed above, there are eight feasible structures that may satisfy market-clearing and other conditions for a general equilibrium.

Structure AA, as shown in panel (1) of Fig.1, is an autarky structure where individuals in both countries choose self-sufficiency (configuration A). Structure AD, shown in panel (2) of Fig.1, is asymmetric between the two countries: all individuals in country 1 choose autarky configuration A, while some individuals in country 2 choose configuration $(x / y)$ and others choose configuration $(y / x)$. Hence, there is domestic division of labor and related domestic trade in country 2, but without international division of labor and related international trade. Structure DA is symmetric to structure AD: country 1 has domestic division of labor and country 2 is in autarky. This structure involves a type I dual structure between countries.

Structure CP, shown in panel (4) of Fig.1, involves a type II dual structure between the two countries as well as in country 2. Some individuals in country 2 choose configuration $(y / x)$, the rest of the population choose autarky, and all individuals in country 1 choose configuration $(x / y)$. There is a dual structure between professional individuals choosing $(y / x)$ and self-sufficient individuals in country 2 despite their ex ante identical characteristics. The professional individuals in country 2 are involved in international trade with country 1 . Structure PC is symmetric to structure CP.

Structure CC, shown in panel (6) of Fig.1, is international complete division of labor between two countries in which all individuals in country 1 choose configuration $(x / y)$ and all individuals in country 2 choose configuration $(y / x)$.

In Structure CD, shown in panel (7) of Fig.1, country 1 has only international trade whereas country 2 has both international and domestic trade, and country 1 exports good $x$ and country 2 exports good $y$.

Structure DC, shown in panel (8), is the same as structure PC except that those individuals choosing autarky in country 1 in structure $\mathrm{PC}$ choose configuration $(y / x)$ instead in structure DC. Hence, in structure DC all individuals completely specialize, but country 1 is involved in both domestic and international trade, whereas country 2 is involved only in international trade. Also, country 1 exports good $x$ and country 2 exports good $y$.

Since the optimal values of individuals' decision variables are discontinuous across structures, we introduce the concept of corner equilibrium. A 
FIG. 1. Configurations and Structures

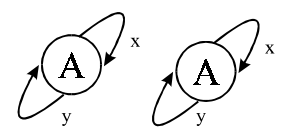

country 1 country 2

(1) Structure AA

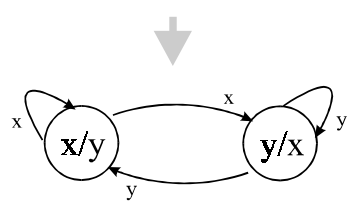

country 1 country 2

(6) Structure CC

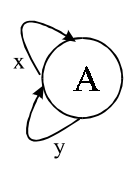

country 1

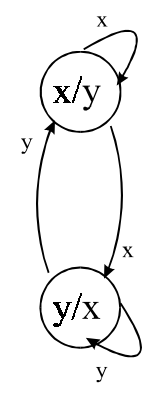

country 2
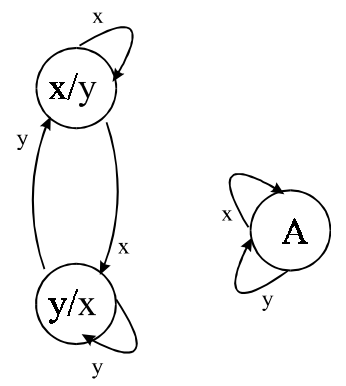

country 1 country 2

(2) Structure AD

(3) Structure DA
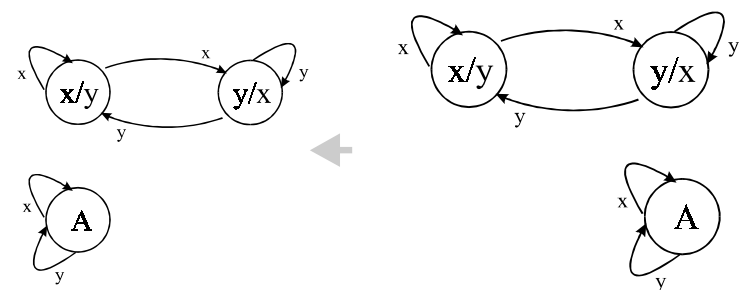

country 1

country 2

country 1 country

(5) Structure PC

(4) Structure CP

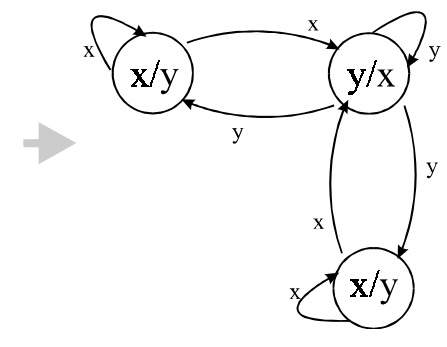

country 1 country 2

(7) Structure CD

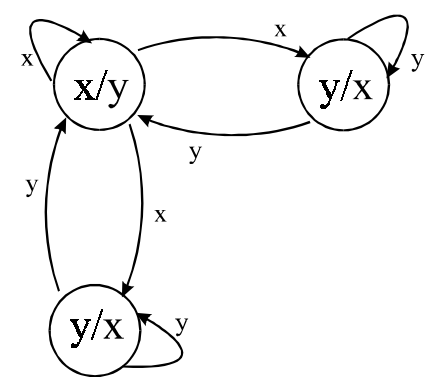

country 1 country 2

(8) Structure DC 
corner equilibrium is defined as a set of relative prices of traded goods, numbers of individuals choosing different configurations, and the resource allocation in a given structure that satisfies the following conditions: (1) at the set of prices, the utility of each individual in both countries is maximized; (2) markets clear; (3) utilities of all individuals in the same country are equalized. The general equilibrium is the corner equilibrium where each individual's utility is maximized with respect of all possible configurations under the corner equilibrium prices.

To solve for the general equilibrium, we first apply the marginal analysis to solve for the corner equilibrium for each of the eight feasible structures. For instance, given structure PC, some individuals in country 1 choose configuration $(x / y)$, the rest of the population choose autarky, the number of choosing $(x / y)$ and choosing autarky are $M_{1 x}$ and $M_{1 A}$, respectively, $M_{1 x}+M_{1 A}=M_{1}$, and all individuals in country 2 choose configuration $(y / x)$, that is, $M_{2 y}=M_{2}$. For simplicity, we assume $\beta=0.5$. The decision problems for individuals in country 1 who choose configuration $(x / y)$ and autarky are respectively:

$$
\begin{aligned}
\max _{x_{1}, y_{1}^{d}} U_{1(x / y)} & =x_{1}^{1 / 2}\left(k_{1} y_{1}^{d}\right)^{1 / 2}, \\
\text { s.t. } x_{1}+x_{1}^{s} & =c(2-b) \\
p x_{1}^{s} & =y_{1}^{d} . \\
\max _{x_{1}, y_{1}} U_{1(A)} & =x_{1}^{1 / 2}\left(y_{1}\right)^{1 / 2} \\
\text { s.t. } x_{1} & =c\left(L_{1 x}-b\right) \\
y_{1} & =L_{1 y} \\
L_{1 x}+L_{1 y} & =2 .
\end{aligned}
$$

Since all individuals in country 1 are ex ante identical, utilities of individuals choosing different configurations should be equalized in equilibrium. This condition can determine the price of good $x$ in terms of good $y, p$. Solving above two decision problems and applying $U_{1(x / y)}=U_{1(A)}$, we can derive relative price $p=1 / k_{1} c$. Then we solve for the decision problem of an individual in country 2 . Since all individuals in country 2 choose specialization in producing good $y$, their decision problem is :

$$
\begin{aligned}
\max _{x_{2}^{d}, y_{2}} U_{2(y / x)} & =\left(k_{2} x_{2}^{d}\right)^{1 / 2}\left(y_{2}\right)^{1 / 2} \\
\text { s.t. } y_{2}+y_{2}^{s} & =2 a \\
y_{2}^{s} & =p x_{2}^{d} .
\end{aligned}
$$

We can solve $M_{1 x}$ and $M_{1 A}$ from the market-clearing condition. The corner equilibrium in structure PC can be solved, as shown in Table 1. 
TABLE 1.

Corner Equilibrium

\begin{tabular}{|l|l|l|}
\hline Structure & $\begin{array}{l}\text { Relative price } \\
\text { of } x \text { to } y\end{array}$ & $\begin{array}{l}\text { Numbers of individuals choosing } \\
\text { various configurations }\end{array}$ \\
\hline AA & & $M_{1 A}=M_{1}, M_{2 A}=M_{2}$ \\
\hline CP & $4 k_{2} a / c(2-b)^{2}$ & $\begin{array}{l}M_{1 x}=M_{1}, M_{2 y}=2 M_{1} k_{2} /(2-b), \\
M_{2 A}=M_{2}-2 M_{1} k_{2} /(2-b)\end{array}$ \\
\hline PC & $1 / k_{1} c$ & $\begin{array}{l}M_{1 x}=M_{1}, M_{2 y}=2 M_{1} k_{2} /(2-b), \\
M_{2 A}=M_{2}-2 M_{1} k_{2} /(2-b)\end{array}$ \\
\hline $\mathrm{AD}$ & $2 a / c(2-b)$ & $M_{1 A}=M_{1}, M_{2 x}=M_{2 y}=M_{2} / 2$ \\
\hline $\mathrm{DA}$ & $2 / c(2-b)$ & $M_{1 x}=M_{1 y}=M_{1} / 2, M_{2 A}=M_{2}$ \\
\hline $\mathrm{CC}$ & $2 a M_{2} / c(2-b) M_{1}$ & $M_{1 x}=M_{1}, M_{2 y}=M_{2}$ \\
\hline $\mathrm{DC}$ & $2 / c(2-b)$ & $\begin{array}{l}M_{1 x}=\left(M_{1}+a M_{2}\right) / 2, M_{2 y}=M_{2} \\
M_{1 y}=\left(M_{1}-a M_{2}\right) / 2\end{array}$ \\
\hline $\mathrm{CD}$ & $2 a / c(2-b)$ & $\begin{array}{l}M_{1 x}=M_{1}, M_{2 x}=\left(M_{2}-M_{1}\right) / 2 \\
M_{2 y}=\left(M_{1}+M_{2}\right) / 2\end{array}$ \\
\hline
\end{tabular}

Following a similar procedure, we have solved the corner equilibria in other structures. The results are summarized in Table 1. For the given corner equilibrium price in a structure, we can compare each individual's utilities across different configurations. An individual would choose the configuration that generates a utility level that is not lower than other alternative configurations. This condition that all individuals' utilities are maximized across all possible configurations defines a parameter subspace within which the corner equilibrium is the general equilibrium. The general equilibrium and their corresponding parameter subspaces are summarized in Table 2.

The results in Table 2 suggest that transaction efficiency determines the equilibrium level of the division of labor - as transaction efficiency improves, the equilibrium level of the division of labor jumps from autarky to partial division of labor (structure $\mathrm{CP}$ or PC ), then to the complete division of labor (structure $\mathrm{CC}, \mathrm{DC}, \mathrm{CD})$. In the transitional structure (CP or $\mathrm{PC}$ ), the country with the lower transaction efficiency produces two goods and receives no gains from trade.

In Table 2, $\mathrm{C}$ stands for complete specialization in a country, D stands for the domestic division of labor in a country, A stands for autarky in a country, $\mathrm{P}$ stands for the partial division of labor where the population is divided between autarky and specialization in a country. Hence, structure AA involves autarky in both countries, structures AD and DA involve autarky in one country and the division of labor in the other, structures PC 
TABLE 2.

Walrasian Equilibrium and Its Inframarginal Comparative Statics

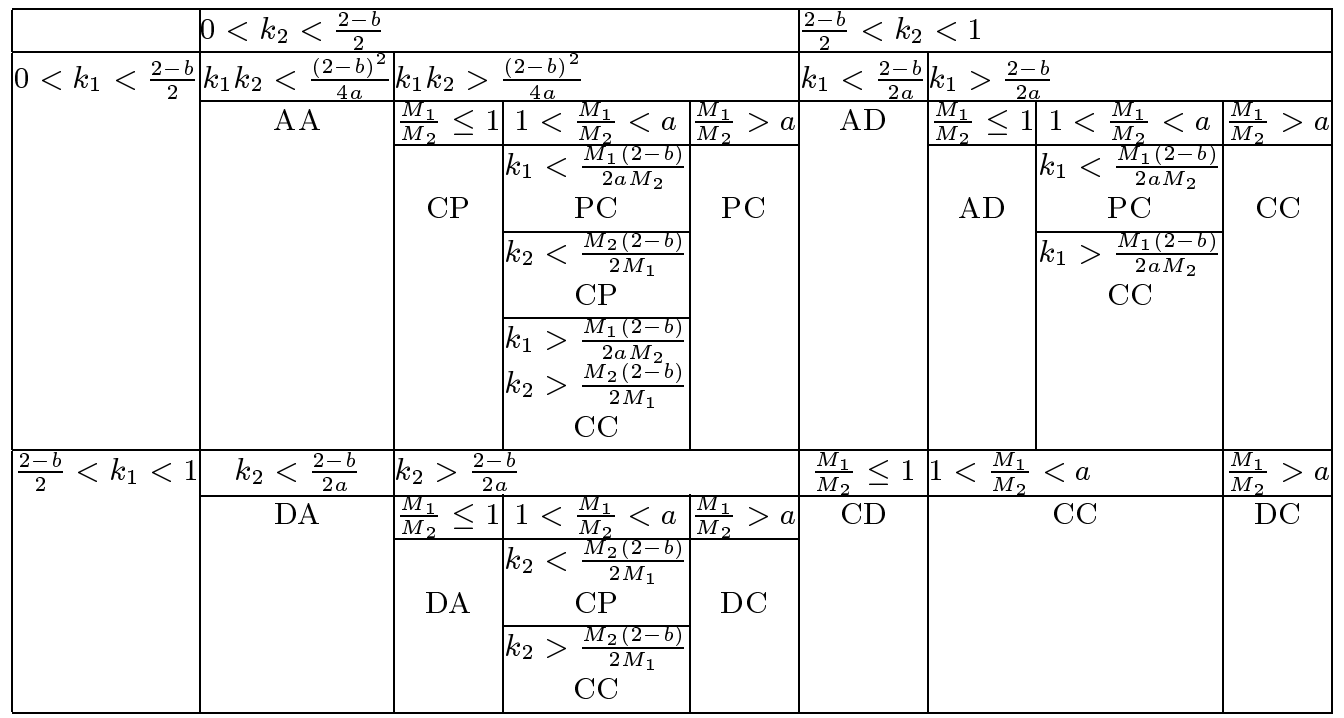

and $\mathrm{CP}$ involve complete specialization in one country and coexistence of autarky and complete specialization in the other. The country with the lower transaction efficiency in this structure looks like underdeveloped in the sense that it receives none of gains from trade and income differential between it and the other country with higher transaction efficiency increases as a result of a shift of equilibrium from autarky to this structure. Also, ex ante identical individuals in the less developed country in this structure are divided between a professional occupation that trades with the foreign country and those who are self-sufficient and not involved in commercialized production. These self-sufficient individuals look like in underemployment since they cannot find a job to work for the market. All individuals completely specialize in structures CD and CC. But CC involves complete specialization of both countries in the absence of domestic trade, whereas CD involves complete specialization in country 1 and domestic division of labor in country 2. Fig.1 illustrates the equilibrium structures. We say the level of the division of labor increases if occurrence of letter $\mathrm{A}$ or $\mathrm{P}$ decreases or the occurrence of letter $\mathrm{D}$ or $\mathrm{C}$ increases in a structure.

Hence, the inframarginal comparative statics of general equilibrium can be summarized as follows. 
Proposition 2.1. If transaction efficiencies are very low in the two countries, the general equilibrium is autarky where no domestic and international trade takes place. As the transaction conditions in one country improve, a type I dual structure emerges from the coexistence of domestic division of labor in one country and autarky in the other (structure AD or DA). As trading efficiencies further improve, a type II dual structure emerges (structure CP or PC) where all gains from trade go to the country that completely specializes and the population in the country with a lower trading efficiency is divided between the commercialized sector and autarky. If the transaction efficiencies in both countries sufficiently improve, the equilibrium jumps to the complete international division of labor. In this process, the equilibrium aggregate productivity converges to the aggregate production possibility frontier.

Since marginal rate of substitution and marginal rate of transformation must be equalized for each individual in autarky, the equilibrium aggregate productivity occurs under the production possibility frontier if autarky is the general equilibrium. As transaction conditions are improved, the equilibrium aggregate productivity becomes closer to the PPF. Zhou, Sun, and Yang (1998) prove that a general equilibrium for a general class of models with consumer-producers and endogenous and exogenous comparative advantages exists if the set of individuals is a continuum and that the general equilibrium is Pareto optimal. Hence, our inframarginal comparative statics imply that if transaction efficiencies are very low, the Pareto optimal is not associated with the PPF because of the trade off between (endogenous and exogenous) comparative advantages and transaction costs. As transaction conditions are improved, the equilibrium as well as Pareto optimal become closer to the PPF. This result can be used to explore development implications of transaction conditions and intimate relationship between trade dependence and economic development. Improvements in transaction conditions generate expansion of the network of trade, which increases the equilibrium aggregate productivity.

Also, our results can be used to explain "underdevelopment phenomenon" in the transitional period of economic development. As an economy develops from autarky to high level of international trade, real income differential between developed countries, which have better transaction conditions, and less developed countries may increase due to the unequal distribution of gains from international trade. This generates trade conflict between developed and less developed countries, which may motivate rent-seeking via tariff policy. We turn to this issue in the next section. 


\section{ENDOGENOUS TRADE POLICY REGIME}

This section introduces governments' decisions on trade policies into the model. The governments can choose from three trade policy regimes: a Nash tariff game where each government chooses its own tariff rate, taking the other country's tariff rate as given; Nash tariff bargaining; and laissez faire.

Since the welfare effects of tariff are different for different trade structures, we examine structures separately, starting with $\mathrm{CC}$, then moving on to structures DC and CD, finally to structure PC and CP. Because of the symmetry between DC and CD, and between CP and PC, we only need to consider structures $\mathrm{CC}, \mathrm{CD}$, and $\mathrm{CP}$.

\subsection{Structure CC: Complete International Division of Labor}

Assume that the government in each country can impose tariff on imported goods to maximize its citizen's welfare. Tariff revenue is equally distributed among the domestic buyers of the imported goods. In structure CC, the decision problems for individuals in country 1 and country 2 are:

$$
\begin{aligned}
\max _{x_{1}, y_{1}^{d}} U_{1} & =x_{1}^{1 / 2}\left(k_{1} y_{1}^{d}\right)^{1 / 2}, & \max _{x_{2}^{d}, y_{2}} U_{2} & =\left(k_{2} x_{2}^{d}\right)^{1 / 2}\left(y_{2}\right)^{1 / 2}, \\
\text { s.t. } x_{1}+x_{1}^{s} & =c(2-b), & \text { s.t. } y_{2}+y_{2}^{s} & =2 a, \\
p_{x} x_{1}^{s}+R_{1} & =p_{y}\left(1+t_{1}\right) y_{1}^{d}, & p_{y} y_{2}^{s}+R_{2} & =p_{x}\left(1+t_{2}\right) x_{2}^{d},
\end{aligned}
$$

where $t_{i}$ is the tariff rate in country $i$ and $R_{i}$ is the tariff revenue received by an individual in country $i, R_{1}=t_{1} p_{y} y_{1}^{d}$ and $R_{2}=t_{2} p_{x} x_{2}^{d}$ in equilibrium.

Solving the decision problems, we obtaine the supply and demand functions for good $x$ and good $y$ :

$$
\begin{aligned}
x_{1} & =\frac{c(2-b)}{2} \frac{2\left(1+t_{1}\right)}{2+t_{1}}, & x_{1}^{s} & =\frac{c(2-b)}{2} \frac{2}{2+t_{1}}, y_{1}^{d}=\frac{c(2-b)}{2} \frac{2}{2+t_{1}} \frac{p_{x}}{p_{y}} \\
y_{2} & =a \frac{2\left(1+t_{1}\right)}{2+t_{1}}, & y_{2}^{s} & =a \frac{2}{2+t_{1}},
\end{aligned}
$$

Using the market-clearing condition for good $x$, we can solve for the price of good $x$ in terms of good $y$ :

$$
\frac{p_{y}}{p_{x}}=\frac{M_{1}}{M_{2}} \frac{c(2-b)}{2 a} \frac{2+t_{2}}{2+t_{1}} .
$$

Substituting the demand and supply functions and the relative price into the utility functions, we get the corner-equilibrium levels of utilities 
for individuals in the two countries:

$$
\begin{aligned}
& u_{1}\left(t_{1}, t_{2}\right)=\left[k_{1} \frac{M_{2}}{M_{1}} \frac{a c(2-b)}{2} \frac{4\left(1+t_{1}\right)}{\left(2+t_{1}\right)\left(2+t_{2}\right)}\right]^{1 / 2}, \\
& u_{2}\left(t_{1}, t_{2}\right)=\left[k_{2} a^{2} \frac{M_{1}}{M_{2}} \frac{c(2-b)}{2 a} \frac{4\left(1+t_{2}\right)}{\left(2+t_{1}\right)\left(2+t_{2}\right)}\right]^{1 / 2} .
\end{aligned}
$$

We now look at how governments may choose different trade policy regimes.

\subsubsection{Nash tariff game}

Differentiation of the two expressions with respect to $t_{i}$ yields:

$$
\frac{\partial u_{1}}{\partial t_{1}}>0, \quad \frac{\partial u_{1}}{\partial t_{2}}<0, \quad \frac{\partial u_{2}}{\partial t_{2}}>0, \quad \frac{\partial u_{2}}{\partial t_{1}}<0 .
$$

The above four inequalities suggest that, taking the other country's tariff rate as given, each country can improve its citizens' welfare by imposing a tariff. Thus the governments could play a Nash tariff game rather than adopt laissez faire trade policies. However, if the governments in the two countries do play a Nash tariff game, the above four inequalities imply that in the Nash equilibrium each country would impose a tariff to such a high level that individuals in the other country is just indifferent between participating in international trade and autarky. The Nash equilibrium tariff rates $\left(t_{1}^{*}, t_{2}^{*}\right)$ are determined by equalization conditions between utility in structure $\mathrm{AA}$ and in structure $\mathrm{CC}$ :

$$
\begin{aligned}
u_{1}\left(t_{1}^{*}, t_{2}^{*}\right) & =u_{1}(A), \quad u_{2}\left(t_{1}^{*}, t_{2}^{*}\right)=u_{2}(A), \\
t_{1}^{*} & =\frac{1}{8 k_{1}} \frac{M_{1}}{M_{2}}(2-b)\left(2+t_{1}^{*}\right)\left(2+t_{2}^{*}\right)-1, \\
t_{2}^{*} & =\frac{1}{8 k_{2}} \frac{M_{2}}{M_{1}}(2-b)\left(2+t_{1}^{*}\right)\left(2+t_{2}^{*}\right)-1,
\end{aligned}
$$

and the solution $\left(t_{1}^{*}, t_{2}^{*}\right)$ are implicitly given by the two equations above.

In other words, if the two governments use tariff to compete for a larger share of the gains from trade, there will be a tariff war which would exhaust all the gains from trade. This is an example of the prisoner's dilemma.

\subsubsection{Nash tariff negotiation}

Alternatively, the two governments can play a Nash bargaining game, that is, they can negotiate over tariff rates. The Nash tariff negotiation 
maximizes the Nash product, which is the product of the gains from trade received by individuals in each country. The gains from trade are measured by the difference in the utility between participating in trade (structure $\mathrm{CC}$ in this case) and staying in structure AA, AD, or DA. The Nash tariff negotiation equilibrium is given by the solution of the following problem:

$$
\max _{t_{1}, t_{2}} V \equiv\left[u_{1}\left(t_{1}, t_{2}\right)-u_{1}(A)\right]\left[u_{2}\left(t_{1}, t_{2}\right)-u_{2}(A)\right]
$$

where $u_{i}(A)$ denotes the utility of a person in country $i$ in an alternative structure with autarky or domestic division of labor. The first-order conditions for this problem yield $\left(1+t_{1}\right)\left(1+t_{2}\right)=1$, which gives the equilibrium tariff $t_{1}^{*}=t_{2}^{*}=0$. In other words, the Nash tariff negotiation generates trade liberation.

The result of a tariff negotiation is in sharp contrast with the result of a Nash tariff game with the latter leading to complete dissipation of the gains from trade because of the prisoners' dilemma. This provides an explanation as to why trade negotiations may be essential for trade liberalization and for the full exploitation of the gains from trade.

If the two governments can choose between the Nash tariff war and Nash tariff negotiation, they will certainly choose the latter. Hence, if structure $\mathrm{CC}$ occurs in equilibrium and if the governments are allowed to choose policy regimes, the general equilibrium trade policy will be free trade resulted from a Nash tariff negotiation.

\subsection{Structures CD: Partial International Division of Labor}

We now turn to the structures with partial international division of labor, structure CD, to examine the choices of trade policies.

In country 1 , the decision problem for an individual specializing in good $x$ is:

$$
\begin{aligned}
\max _{x_{1}, y_{1}^{d}} U_{1} & =x_{1}^{1 / 2}\left(k_{1} y_{1}^{d}\right)^{1 / 2} \\
\text { s.t. } x_{1}+x_{1}^{s} & =c(2-b) \\
p_{x} x_{1}^{s}+R_{1} & =p_{y}\left(1+t_{1}\right) y_{1}^{d} .
\end{aligned}
$$

The solution of this problem is:

$$
x_{1}=\frac{c(2-b)}{2} \frac{2\left(1+t_{1}\right)}{2+t_{1}}, \quad x_{1}^{s}=\frac{c(2-b)}{2} \frac{2}{2+t_{1}}, \quad y_{1}^{d}=\frac{c(2-b)}{2} \frac{2}{2+t_{1}} \frac{p_{x}}{p_{y}} .
$$


In country 2, the decision problem for an individual specializing in good $x$ and that for an individual specializing in good $y$ are, respectively

$$
\begin{aligned}
\max _{x_{2}, y_{2}^{d}} U_{2}(x / y) & =x_{2}^{1 / 2}\left(k_{2} y_{2}^{d}\right)^{1 / 2}, \\
\text { s.t. } x_{2}+x_{2}^{s} & =c(2-b), \\
p_{x}^{D} x_{2}^{s} & =p_{y} y_{2}^{d} . \\
\max _{x_{2}^{d}, y_{2}} U_{2}(y / x) & =\left(k_{2} x_{2}^{d}\right)^{1 / 2}\left(y_{2}\right)^{1 / 2}, \\
\text { s.t. } y_{2}+y_{2}^{s} & =2 a, \\
p_{y} y_{2}^{s}+R_{2} & =p_{x}^{D} x_{22}^{d}+p_{x}\left(1+t_{2}\right) x_{12}^{d} .
\end{aligned}
$$

where $p_{x}^{D}$ is the price of good $x$ in country $2, p_{x}^{D}=p_{x}\left(1+t_{2}\right), x_{12}^{d}$ and $x_{22}^{d}$ are foreign demand and domestic demand of good $x$ by individuals choosing configuration $(y / x)$ in country 2 , respectively, $t_{i}$ is the tariff rate in country $i, R_{i}$ is the tariff revenue received by an individual purchasing foreign good in country $i$, and $R_{1}=t_{1} p_{y} y_{1}^{d}, R_{2}=t_{2} p_{x} x_{12}^{d}, x_{2}^{d}=x_{12}^{d}+x_{22}^{d}$.

Solving above two problems yields:

$$
\begin{aligned}
& x_{2}=\frac{c(2-b)}{2}, x_{2}^{s}=\frac{c(2-b)}{2}, y_{2}^{d}=\left(1+t_{2}\right) \frac{p_{x}}{p_{y}} \frac{c(2-b)}{2}, \\
& y_{2}=a+t_{2} \frac{p_{x}}{p_{y}} \frac{M_{1}}{M_{2 y}} \frac{c(2-b)}{4} \frac{2}{2+t_{1}}, y_{2}^{s}=a-t_{2} \frac{p_{x}}{p_{y}} \frac{M_{1}}{M_{2 y}} \frac{c(2-b)}{4} \frac{2}{2+t_{1}}, \\
& x_{2}^{d}=\frac{1}{1+t_{2}} \frac{p_{y}}{p_{x}}\left[a+t_{2} \frac{p_{x}}{p_{y}} \frac{M_{1}}{M_{2 y}} \frac{c(2-b)}{4} \frac{2}{2+t_{1}}\right] .
\end{aligned}
$$

Using the utility equalization condition and the market-clearing condition for either good, we obtain the corner equilibrium in structure CD:

$$
\begin{aligned}
\frac{p_{x}}{p_{y}} & =\frac{2 a}{c(2-b)} \frac{\left[2 M_{1}+M_{2}\left(2+t_{1}\right)\right]}{\left[2 M_{1}+M_{2}\left(2+t_{1}\right)\left(1+t_{2}\right)\right]}, \\
M_{2 y} & =\frac{2 M_{1}\left(1+t_{2}\right)+M_{2}\left(1+t_{2}\right)\left(2+t_{1}\right)}{2\left(1+t_{2}\right)\left(2+t_{1}\right)}, \\
u_{1}\left(t_{1}, t_{2}\right) & =k_{1} \frac{a c(2-b)}{2} \frac{4\left(1+t_{1}\right)\left[2 M_{1}+M_{2}\left(2+t_{1}\right)\right]}{\left(2+t_{1}\right)^{2}\left[2 M_{1}+M_{2}\left(2+t_{1}\right)\left(1+t_{2}\right)\right]} \\
u_{2}\left(t_{1}, t_{2}\right) & =k_{2} \frac{a c(2-b)}{2} \frac{\left(1+t_{2}\right)\left[2 M_{1}+M_{2}\left(2+t_{1}\right)\right]}{\left[2 M_{1}+M_{2}\left(2+t_{1}\right)\left(1+t_{2}\right)\right]} .
\end{aligned}
$$

From the corner-equilibrium solution, we obtain

$$
\frac{\partial u_{1}}{\partial t_{1}}<0, \quad \frac{\partial u_{1}}{\partial t_{2}}<0, \quad \frac{\partial u_{2}}{\partial t_{1}}<0, \quad \frac{\partial u_{2}}{\partial t_{2}}>0
$$


Clearly, country 2 would not choose free-trade policies. If it plays a Nash game, it would want its tariff rate to be as high as possible. But since

$$
\frac{\partial u_{1}}{\partial t_{2}}<0
$$

country 2 needs to ensure that its tariff rate is not so high as to drive country 1 out of international trade. Thus, the optimum tariff rate for country 2 is determined by the utility equalization between structure CD and structure AA for individuals in country 1, which (after some algebraic simplification) is

$$
u_{1}\left(0, t_{2}^{*}\right)=u_{1}(A) \quad \text { or } \quad t_{2}^{*}=\frac{2 M_{1}(2 a-2+b)+4 a M_{2}}{(2-b) M_{2}}-1 \text {. }
$$

Since $\frac{\partial u_{1}}{\partial t_{1}}<0$, the optimum tariff rate for country 1 is zero. therefore, if structure CD occurs in equilibrium, the result of a Nash tariff game would be the coexistence of an unilateral laissez faire policy by country 1 and unilateral protection tariff by country 2 .

In a Nash tariff game, country 2 gets most the gains from trade. Since a Nash tariff negotiation would mean sharing the gains from trade, country 2 does not have an incentive to participate in a tariff negotiation. Thus even if the governments in both countries are allowed to choose between the Nash tariff game and Nash tariff negotiation, the Nash tariff negotiation would not be chosen by country 2 . As a result, the equilibrium trade policy regime would feature the coexistence of unilateral protection tariff and unilateral laissez faire.

\subsection{Structures CP: Dual Economy}

In structure $\mathrm{CP}$, all individuals in country 1 choose configuration $(x / y)$, so $M_{1 x}=M_{1}$. Some individuals in country 2 choose configuration $(y / x)$, other individuals choose autarky. Numbers choosing $(y / x)$ and choosing autarky are $M_{2 y}$ and $M_{2 A}$, respectively, $M_{2 y}+M_{2 A}=M_{2}$. The decision problem of individuals in country 1 is the same as in structure CC. For individuals in country 2 , we assume that tariff revenue is equally distributed to each individual, so the decision problems of individuals choosing $(y / x)$ 
and choosing autarky in country 2 are respectively:

$$
\begin{aligned}
& \max _{x_{2}^{d}, y_{2}} U_{2}(y / x)=\left(k_{2} x_{2}^{d}\right)^{1 / 2}\left(y_{2}\right)^{1 / 2}, \\
& \text { s.t. } y_{2}+y_{2}^{s}=2 a \text {, } \\
& p_{y} y_{2}^{s}+R_{2}=p_{x}\left(1+t_{2}\right) x_{12}^{d} \text {. } \\
& \max _{x_{2}, y_{2}, x_{2 A}^{d}, y_{2 A}^{d}} u_{2}(T A)=\left(x_{2}+k_{2} x_{2 A}^{d}\right)^{1 / 2}\left(y_{2}+k_{2} y_{2 A}^{d}\right)^{1 / 2}, \\
& \text { s.t. } x_{2}=c\left(L_{2 x}-b\right) \text {, } \\
& y_{2}=a L_{2 y} \text {, } \\
& L_{2 x}+L_{2 y}=2 \text {, } \\
& p_{x}\left(1+t_{2}\right) x_{2 A}^{d}+p_{y} y_{2 A}^{d}=R_{2},
\end{aligned}
$$

where TA denotes the decision problem in autarky with government tariff, $x_{2 A}^{d}$ and $y_{2 A}^{d}$ are the demand for good $x$ and $y$, respectively, $R_{2}=$ $\frac{M_{2 y} t_{2} p_{x}+M_{2 A} t_{2} x_{2 A}^{d}}{M_{2}}$ is the per capita tariff revenue. For simplicity, we assume $x_{2 A}^{d}=0$, that is to say, individuals who choose autarky do not buy imported good.

Solving above problems yields the demand function. Using the utilityequalization condition and market-clearing conditions yields the relative price, numbers of individuals choosing different configurations, and the corner-equilibrium utility level:

$$
\begin{aligned}
\frac{p_{x}}{p_{y}} & =\frac{a}{c\left(1+t_{2}\right)}, \\
M_{2 y} & =\frac{2 M_{2}\left(1+t_{2}\right)\left(2 \sqrt{k_{2}}-2+b\right)}{t_{2}\left(2 k_{2}-2+b\right)}, \\
u_{1}\left(t_{1}, t_{2}\right) & =\left[k_{1} a c(2-b)^{2} \frac{\left(1+t_{1}\right)}{\left(1+t_{2}\right)\left(2+t_{1}\right)^{2}}\right]^{1 / 2} . \\
u_{2}(y / x) & =u_{2}(T A)=\left[\frac{a c\left(2-b-2 k_{2}\right)^{2}}{4\left(1-\sqrt{k_{2}}\right)^{2}}\right]^{1 / 2} .
\end{aligned}
$$

If $k_{2}<\frac{(2-b)^{2}}{4}$, we have $M_{2 y}<M_{2}$. Hence, $k_{2}<\frac{(2-b)^{2}}{4}$ is a necessary condition that structure $\mathrm{CP}$ occurs in equilibrium. It is easy to show $u_{2}(y / x)=u_{2}(T A)>u_{2}(A)$, this implies the government in country 2 prefers a tariff on imported goods. But $\frac{\partial u_{1}}{\partial t_{1}}<0$ and $\frac{\partial u_{1}}{\partial t_{2}}<0$, thus, the optimum tariff rate for country 1 is zero. The equilibrium trade policy regime would feature the coexistence of unilateral protection tariff and unilateral laissez faire. 
We may draw the distinction between the exogenous transaction costs coefficient and the endogenous transaction costs caused by the deadweight of tariff. Exogenous transaction costs can be seen before individuals have made their decisions. Endogenous transaction costs are caused by conflicts between self-interested decisions that generate distortions. Following the method used in section 2, we can prove that in this extended model, the general equilibrium jumps from autarky to the partial division of labor, where unilateral protection tariff in the less developed country and unilateral laissez faire in the developed economy coexist, then to the complete division of labor, where tariff negotiation generates bilateral free trade, as the exogenous transaction costs coefficient decreases. In the transitional period with partial division of labor, endogenous transaction costs are caused by trade conflicts between the developed and less developed countries. There are two ways for a less developed country to get more gains from trade in the transitional period. One is to improve transaction conditions in the less developed country, so that the equilibrium jumps to the complete division of labor that ensures bilateral incentives for tariff negotiation, which leads to trade liberalization. The other is that the less developed country imposes a stiff tariff to get greater gains from trade at the cost of the partner. The first way is to get a larger share by enlarging the pie and the second way is to get a larger share of a shrinking pie.

The results are summarized as follows.

Proposition 3.1. As exogenous transaction conditions are improved, the equilibrium jumps from autarky to the partial international division of labor where coexistence of unilateral protection tariff and unilateral laissez faire generates endogenous transaction costs, then to the complete international division of labor where tariff negotiation leads to free trade and eliminates endogenous transaction costs.

Proposition 3.1 may be used to explain two phenomena. First, despite the distortions caused by tariff, tariff may be used by the government in a less developed economy with low transaction efficiency to get a larger share of gains from trade, since the Walrasian equilibrium terms of trade with no tariff may be very unfavorable to the less developed country. Second, when transaction condition is inadequate and when the equilibrium is associated with an intermediate level of the division of labor, a country that has low transaction efficiency and does not completely specialize may prefer a unilateral tariff, whereas the other country that has higher transaction efficiency and completely specializes may prefer a unilateral laissez faire 
regime. But as transaction conditions improve further, all countries may prefer tariff negotiations to a unilateral tariff.

In the 16th century, unilateral tariff was advocated by mercantilists as a means of rent seeking in international trade. It gave way to trade liberalization in the 18th and 19th centuries in some European countries. However, even after the World War II, many governments in developing countries have still adopted unilateral tariff protection. More recently, tar-

iff negotiations have become increasingly prevalent. Some economists use the Walrasian model to explain the emergence of the laissez faire regime, but the model cannot explain why other trade regimes persisted in many countries for a long period of time. Other economists use the theory of import substitution and export substitution to explain the transition from unilateral tariff to trade liberalization (see, for instance, Balassa, 1980), but the theory cannot explain why the laissez faire regime was unstable even between developed countries; why unilateral protection tariff and laissez faire regime may coexist; or why tariff negotiations may be necessary for free trade and for the exploitation of the gains from trade. Proposition 3.1 in this paper seems to offer a more plausible explanation as to why unilateral tariff prevailed in the early stage of economic development; why trade liberalization is preferred in later stages of economic development; and other associated questions.

\section{CONCLUSION}

In this paper, we have introduced transaction costs and endogenous comparative advantage into the Ricardian model. We have also examined governments' choices of different trade policy regimes. An interesting result of this paper is that the equilibrium trade policy regimes are intimately related to the level of international division of labor. At a high level of international division of labor, countries would participate in Nash tariff negotiations that would lead to free trade. If the level of the division of labor is at a level such that one country produces both goods (some of residents in this country completely specialize and the rest of them choose autarky) and determines the terms of trade, then at equilibrium, unilateral tariff and unilateral free trade would coexist. The model provides a plausible story about how a trade policy regime might evolve, and an explanation for the changing tides of trade policy stances in developing countries. 


\section{REFERENCES}

Babbage, C., 1832, On the Economy of Machinery and Manufactures, 4th enlarged edition of 1835, reissued in 1977. New York, M. Kelly.

Balassa, B., 1980, The process of industrial development and alternative development strategies. Princeton University, International Finance Section, Essays in International Finance No. 141.

Cheng, W., J. Sachs, and X. Yang, 2000, An inframarginal analysis of the Ricardian model. Review of International Economics 8, 208-220.

Cheng, W., M. Liu, and X. Yang, 2000, A Ricardo model with endogenous comparative advantage and endogenous trade policy regime. Economic Record 76, 172-182.

Dixit, A. K. and Albert S. Kyle, 1985, The use of protection and subsidies for entry promotion and deterrence. American Economic Review 75, 139-152.

Ekelund, R. and R. Tollison, 1981, Mercantilism as a Rent-Seeking Society. College Station, Texas A \& M University Press.

Gomory, R. E., 1994, A Ricardo model with economies of scale. Journal of Economic Theory 62, 394-419.

Grossman, G. M. and J. Richardson, 1986, Strategic trade policy: a survey of the issues and early analysis. In E. B. Robert and J. D. Richardson, eds., International Trade and Finance, 3rd ed., 95-113. Boston: Little Brown.

Grossman, G. M. and E. Helpman, 1994, Protection for sale. American Economic Review. 84, 833-850.

Grossman, G. M. and E. Helpman, 1995a, The politics of free-trade agreements. American Economic Review 85(4), 668-690.

Grossman, G. M. and E. Helpman, 1995b, Trade wars and trade talks. Journal of Political Economy 103(4), 675-708.

Houthakker, M., 1956, Economics and biology: specialization and speciation. Kyklos 9, 181-189.

Johnson, H. G., 1954, Optimum tariff and retaliation. Review of Economic Studies 21(2), 142-153.

Krueger, A. O., 1974, The political economy of rent-seeking society. American Economic Review 64, 291-303.

Krugman, P. R., 1986, Strategic Trade Policy and the New International Economics. Cambridge: MIT Press.

Mayer, W., 1981, Theoretical considerations on negotiated tariff adjustments. Oxford Economic Papers 33, 135-153.

Mayer, W., 1984, Endogenous tariff formation. American Economic Review 74, 970985.

Morishima, M., 1989, Ricardo's Economics: A General Equilibrium Theory of Distribution and Growth. Cambridge: Cambridge University Press.

Nash, J. F., 1950, The bargaining problem. Econometrica 18, 115-162.

Osborne, Martin J. and A. Rubinstein, 1990,Bargaining and Markets. San Diego: Academic Press, Inc.

Pincus, J. J. 1975, Pressure groups and the pattern of tariffs. Journal of Political Economy 83, 757-778.

Pomfret, R., 1992, Internal trade policy with imperfect competition. Special Papers in International Economics 17, August. 
Riezman, R., 1982, Tariff retaliation from a strategic viewpoint. Southern Economic Journal 48, 583-593.

Rosen, S., 1983, Specialization and human capital. Journal of Labor Economics 1, 43-49.

Wen, M., 1998, An analytical framework of consumer-producers, economies of specialization and transaction costs. In K. Arrow, Y. K. Ng, and X. Yang eds., Increasing Returns and Economic Analysis, London, Macmillan.

Yang, X., 1994, Endogenous comparative advantages and economies of specialization vs. economies of scale. Journal of Economics 60, 29-54.

Zhou, L., G. Z. Sun, and X. Yang, 1998, General equilibria in large economies with endogenous structure of the division of labor. Working Paper, Monash University. 